\title{
Fecundity, reproductive seasonality and maturation size of Callinectes sapidus females (Decapoda: Portunidae) in the Southeast coast of Brazil
}

\author{
Evandro Severino-Rodrigues ${ }^{1}$, Joelson Musiello-Fernandes ${ }^{2}$, Álvaro A.S. Moura ${ }^{3}$, \\ Geisa M.P. Branco ${ }^{3}$ \& Victor O.C. Canéo ${ }^{3}$ \\ 1. Scientific Researcher, Núcleo de Pesquisa e Desenvolvimento do Centro APTA do Pescado Marinho do Instituto de \\ Pesca. Av. Bartolomeu de Gusmão, 192 CEP: 11030-906 Santos- SP, Brazil; evansero@pesca.sp.gov.br \\ 2. Instituto de Pesca-São Paulo, Master Program in Aquaculture and Fisheries in Instituto de Pesca-Brazil; \\ fernandes.joelson@terra.com.br \\ 3. Instituto de Pesca, Trainee, Centro APTA do Pescado Marinho; gutsmoura@hotmail.com, \\ geisaprincipe@hotmail.com,victorcaneo79@hotmail.com
}

Received 08-II-2012. Corrected 20-VIII-2012. Accepted 20-IX-2012.

\begin{abstract}
C. sapidus fisheries has a significant influence on the economy of some countries in North America and has a relative extensive literature in these regions. However, only few papers discuss the ecology of $C$. sapi$d u s$ in the South Atlantic, despite its economic importance in that region. We studied the fecundity, reproductive seasonality and maturation size of $C$. sapidus females captured in the Southeast coast of Brazil from January to December 2002. Females were separated, weighted (Wt), and cephalothorax width (CW) was measured. Furthermore, the eggs-masses were classified according to embryonic development, separated, weighted (We) and fixed. Eggs were also separated and counted, resulting in the average number of eggs per individual (Ne). A total sample of 307 females was collected: 78 young, 130 adults and 99 ovigerous. Ovigerous females showed CW between 7.49 and $15.89 \mathrm{~cm}$ with average of $12.21 \mathrm{~cm}$ and were distributed throughout the sample period, with highest incidence between December and March. The onset of morphological maturity $\left(\mathrm{L}_{50}\right)$ occurred at $\mathrm{CW}=10.33 \mathrm{~cm}$, and the size in which all were mature $\left(\mathrm{L}_{100}\right)$ was $\mathrm{CW}=11.20 \mathrm{~cm}$. Individual fecundity ranged from 689356 to 3438122 with an average of 2006 974. The CW showed a positive growth trend with Ne and We. We concluded that in order to ensure the resource sustainability, it is necessary to prohibit captures of C. sapidus in these regions, especially during summer. Additionally, our studies suggest that the minimum capture size should be $11 \mathrm{~cm}$ of carapace width. Rev. Biol. Trop. 61 (2): 595-602. Epub 2013 June 01.
\end{abstract}

Key words: blue crab, reproductive biology, fisheries resource, estuarine.

Portunids in estuarine and costal ecosystems are typical of tropical and subtropical regions of the Western Atlantic. They are highly abundant and have significant ecological importance in the food chain cycle as predators, consumers of organic matter such as scavangers, and can also serve as components of the diet to other organisms (Lipcius \& Hines 1986, Mantelatto \& Fransozo 1999).

Among the species of the genus Callinectes, the blue crab (Callinectes sapidus Rathbun 1986) is the most economically important in the Western Atlantic, especially in North America, with a rich literature available for the United States of America and Mexico (Millikin \& Williams 1984, Prager et al. 1990). Despite this extensive knowledge on the topic, one cannot generalize the data collected as rules to be applied to other geographic regions (Mantelatto \& Fransozo 1999, Ortiz-Leon et al. 2007). In South America for example, the literature on C. sapidus is scarce and further studies are needed for a better understanding of the biology and comparative comprehension, aiming 
at proper resource management (Villasmil \& Mendonza 2001, Oliveira et al. 2006, Ferreira \& D'incao 2008, Pereira et al. 2009, Mendonça et al. 2010).

C. sapidus is usually found in estuaries, lagoons, river deltas and adjacent ocean regions and distributed in the Western Atlantic from Nova Scotia (USA) to Argentina with introductions in Europe and Japan (Powers 1977, Millikin \& Williams 1984).

The life of C. sapidus occurs in a variety of habitats. It includes population stratification, migratory activities mainly related to gender, ontogenetic, reproductive, and trophic aspects (Mcclintock et al. 1993, Ramach et al. 2009). Inside the estuary and regions of low salinity, there is the predominance of juveniles of both sexes. While the mature males stay in the estuary, adult females and ovigerous females migrate to higher salinity waters (Archambault et al. 1990, Aguilar et al. 2005, Ortiz-Leon et al. 2007, Ramach et al. 2009).

During the displacement from the inner estuary to more saline waters, ovigerous and mature females can migrate long distances. Up to 60-nautical miles traveled in this migratory activity have been observed (Tankersley et al. 1998, Carr et al. 2004). After mating, inseminated females can maintain viable sperm for at least one year. This situation multiple clutches of eggs are produced, with as many as 18-broods over their lifespan. Note that the quantity and viability of stored sperm are independent of female body size (Cargo et al. 1958, Wolcott \& Hines 1990, Dickinson et al. 2006).

The knowledge of reproductive aspects of the $C$. sapidus is of great importance in the management aiming at conservation, since variations in the reproductive stock directly influence their population renewal (Knuckey 1996). Fecundity, reproductive seasonality, and size at sexual maturity are important aspects of reproductive biology of the crab (Rasheed \& Mustaquim 2010). Data is needed to manage crab fisheries on a sustainable basis.

In Brazil, fishing of $C$. sapidus has economic and social importance mainly in the State of São Paulo. Two areas of higher focus are the estuaries of Santos-São Vicente and the Lagoon-Estuarine Complex of Iguape and Cananeia. In the latter, fishing activity is intense and its productivity is monitored in order to maintain its sustainability, thus ensuring ongoing fisheries activities (Severino-Rodrigues et al. 2009, Mendonça et al. 2010).

Despite the economic importance of the species in the region of the Lagoon-Estuarine Complex of Iguape and Cananéia, there is no research on the reproductive aspects of $C$. sapidus. The present work aims to provide an evaluation of the fecundity, reproductive seasonality, and maturation size of $C$. sapidus females, after their migration to more saline waters. It also aims to provide a contribution to the knowledge of the species behavior in the South of the Western Atlantic. Finally, it intends to offer a way to contribute to the definition of management strategies for the species survival in the region.

\section{MATERIALS AND METHODS}

Study area: The study site is located in the estuary exit of the Lagoon-Estuarine Complex of Iguape and Cananéia-SP $\left(25^{\circ} 03\right.$ '2" S $47^{\circ} 54^{\prime} 44^{\prime \prime}$ W) in Southeast Brazil. This region is located at the interface (or communication) with the open sea has about $3.7 \mathrm{~km}$ width with $1.5 \mathrm{~m}$ depth, with an irregular relief formed by sandy banks receiving freshwater inflow from Ribeira de Iguape river and has a $23350 \mathrm{~km}^{2}$ drainage area (Fig. 1). The salinity and water temperature in the study area, range from 28 to 35 with an average of 31 , and 19 to 23.2 with an average of $20.5^{\circ} \mathrm{C}$, respectively, and are influenced by the tide changes and rainfall regimes (Bernades \& Miranda 2001, SeverinoRodrigues et al. 2009).

This region has preserved its natural features and is being recognized by the UNESCO (2005) as the third most productive ecosystem in the South Atlantic. Based on patterns of sustainable development, the region was nominated as a World Natural Heritage Site for its importance to research and knowledge. 


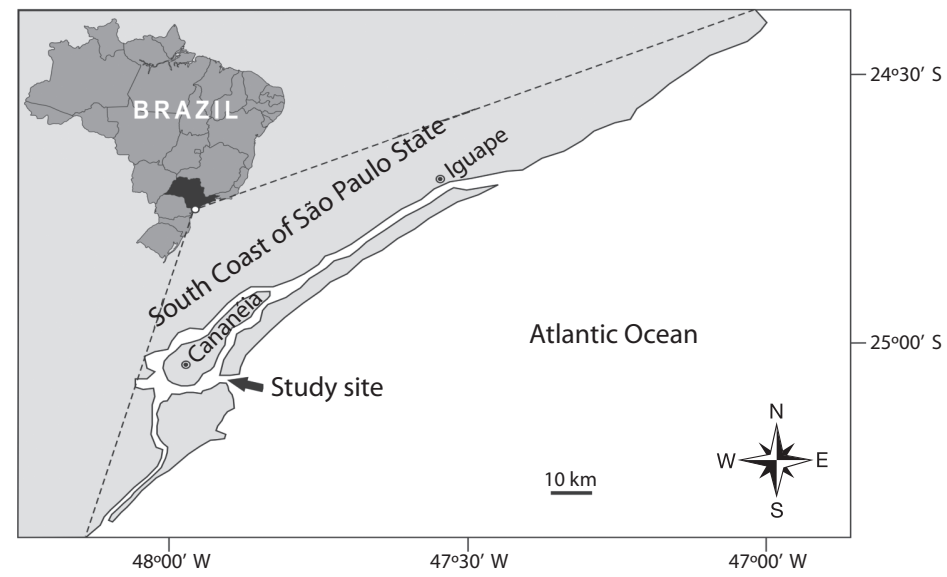

Fig. 1. Sampling area.

The specimens were collected with 12 traps, baited with fish scraps, measuring $60 \times 45 \times 25 \mathrm{~cm}$ (mouths of $12 \times 7 \mathrm{~cm}$ ), with apertures of $2 \mathrm{~cm}$ between nodes. Traps were connected to a cable in the form of a long-line and released in the same region with the aid of a boat. Traps remained immersed for two hours during the low tide of the full moon in a day of each month (January to December, 2002).

Material analysis: Specimens captured were identified to the species level (Williams 1974) and their sex was identified (Taissoun 1973). Females of $C$. sapidus were kept on ice until manipulation.

In the laboratory, each fresh animal without egg masses was measured for carapace width $(\mathrm{CW})$, which is the distance between the lateral spines tips (caliper accuracy of $0.05 \mathrm{~mm}$ ) and weighted $(\mathrm{Wt})$. The maturity stages of juveniles and adults (+ovigerous), were defined macroscopically by the form of the abdomen and the presence of egg masses (Taissoun 1973, Williams 1974). We separated the ovigerous females for fecundity analysis. The Chi-square $\left(\chi^{2}\right)$ test was used to evaluate if the male to female ratio of the population was $1: 1$ at a confidence level of 95\%. The KomolgorovSmirnov (K-S) test was used to verify the normality of the size- frequency distribution to ovigerous females.
Fecundity: The egg masses were classified according to the embryonic development into: I-initial (yellow), II-intermediate (orange), and III-pre-hatching (dark brown) (Ramach et al. 2009), with the fecundity analyses (egg counting) included only in stages I and II. Stage III was not included given that eggs in advanced development stage (III) are more susceptible to accidental release, which may lead to fecundity underestimation (Costa \& Negreiros- Fransozo 1996). The egg masses were removed and weighed. We discounted the weight of pleopods (We) and fixed the material in $70 \%$ alcohol solution. Eggs were separated in a 5\% sodium hypochlorite solution subsampled by the Motoda (1959) separator, and counted. This result was the average number of individual eggs (No).

Reproductive seasonality: The sampling was conducted between January and December (2002), with the idea of establishing the spawning period based on the months of highest concentration and abundance of ovigerous females.

Morphology maturation size: In order to estimate the size at which $50 \%$ of the female population reaches first sexual maturity $\left(\mathrm{L}_{50}\right)$, a software was used resulting into a " $\mathrm{R}$ " of 2.13 (Ihaka \& Gentleman 1996). This software followed a sigmoid model $\left(\mathrm{y}=1 / 1+\exp ^{(\mathrm{LC}-\mathrm{LC} 50)}\right)$, 


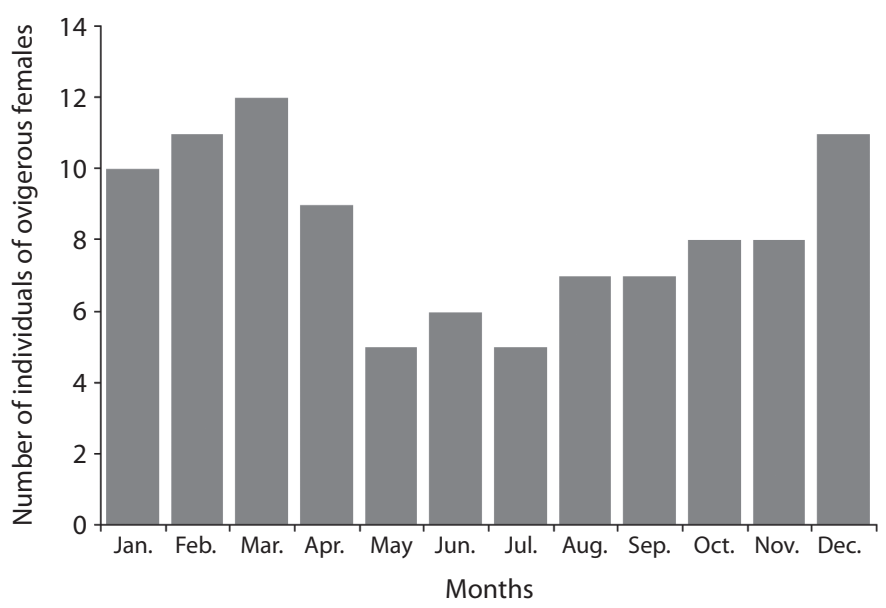

Fig. 2. Number of individuals of ovigerous females of C. sapidus collected monthly during the study period.

and it considered juveniles and adults (+ ovigerous).

\section{RESULTS}

A total of 452 C. sapidus were caught, being 307 females (229 adults and 78 juveniles), corresponding to $67.9 \%$ of the total, and 145 males (114 adults and 31 juveniles), corresponding to $32.1 \%$ of the total, with a sex ratio (M:F) of 1:2.1 significantly different from the expected 1:1 $\left(\chi^{2}=58.06, \mathrm{p}<0.0001\right)$. Adult specimens corresponded to $79.9 \%$ of the sampled population.

The study included only females with 78 juveniles (25\%), 130 adults (43\%) and 99 ovigerous females $(32 \%)$. The smallest female collected had $\mathrm{CW}=4.30$ and the largest $15.89 \mathrm{~cm}$. The mature ones had a CW slightly above $6.95 \mathrm{~cm}$ and the ovigerous females showed amplitude between $7.49 \mathrm{~cm}$ and 15.89 , with an average of $12.21 \mathrm{~cm}( \pm 1.57)$. Ovigerous females occurred throughout the annual cycle with greater participation in December $(n=11)$, January $(\mathrm{n}=10)$, February $(\mathrm{n}=11)$ and March $(\mathrm{n}=12)$ (Fig. 2).

The onset of morphological maturity $\left(\mathrm{L}_{50}\right)$ occurred in females with $\mathrm{CW}=10.33 \mathrm{~cm}$ (Fig. $3)$ and total maturity $\left(\mathrm{L}_{100}\right)$ of $11.25 \mathrm{~cm}$. There was predominance of females with eggs in stage II (57\%), followed by stages I (30\%) and III (13\%).

Individual fecundity ranged from 689356 to 3438122 with average of $2006974( \pm 991$ 071). The overall size-frequency distribution of the ovigerous females showed a normal distribution (K-S test, $\mathrm{p}=0.43$ ), with predominance in classes 11 to $14 \mathrm{~cm}$. The $\mathrm{CW}$ showed a positive growth trend with the number $(\mathrm{Ne})$ and weight (Wt) of the eggs (Table 1).

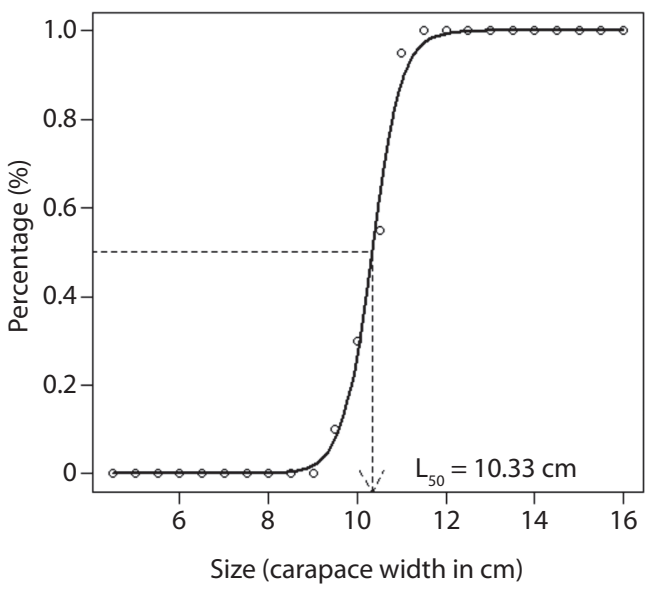

Fig. 3. The morphological sexual maturity size of females of C.sapidus for this region. 
TABLE 1

Number of individuals of ovigerous females, mean fecundity, total weight (Wt) and eggs weight (We) of C. sapidus, by class of carapace width

\begin{tabular}{ccccc} 
Carapace width $(\mathrm{cm})$ & Number of individuals & Mean Fecundity & Wt $(\mathrm{g})$ & We $(\mathrm{g})$ \\
\hline $7-8$ & 2 & 801513 & 39.00 & 13.70 \\
$8-9$ & 3 & 870698 & 49.75 & 13.97 \\
$9-10$ & 5 & 895011 & 63.66 & 13.79 \\
$10-11$ & 8 & 964867 & 83.10 & 14.54 \\
$11-12$ & 17 & 2771227 & 113.49 & 17.03 \\
$12-13$ & 30 & 2397039 & 156.13 & 27.73 \\
$13-14$ & 15 & 2904022 & 166.16 & 33.32 \\
$14-15$ & 4 & 3074085 & 177.35 & 45.15 \\
$15-16$ & 2 & 3308909 & 183.75 & 51.82 \\
\hline
\end{tabular}

\section{DISCUSSION}

The predominance of adult specimens and ovigerous females of $C$. sapidus in the exit of Lagoon-Estuarine Complex of Iguape and Cananéia (SP) characterizes the sampling site as a spawning area. This area is very important in the life cycle of the species, in which mature and ovigerous females move to higher salinity waters for gonads maturation. Salty water ensures lower larval mortality as compared to waters with salinity variations; further, the benefits proposed for offshore larval development include reduced predation, and increased survivorship in high salinity waters due to physiological limitations (Buchanan \& Stoner 1988, Tankersley et al. 1998, Dickinson et al. 2006, Ortiz-Leon et al. 2007, Severino-Rodrigues et al. 2009). The recognition of regions of this type is very important for the understanding of the species life cycle. We believe that the elaboration of management measures can inhibit the capture of blue crabs in these areas and will ensure that the stock can reproduce.

C. sapidus ovigerous females breed throughout the year, predominating in warm months. Such a trend has been observed in most tropical brachyuran (Rasheed \& Mustaquim 2010, Severino-Rodrigues et al. 2012). This reproductive pattern of $C$. sapidus can be classified as "seasonal-continuous" in Brazil, which means higher incidence in certain seasons of the year (Pinheiro \& Fransozo 2002). This is possible due to the continuity of physiological growth and of reproductive process throughout the year. This pattern does not occur in temperate regions, where ovigerous females occur during a few months, being classified as discontinued, which relates to favorable environmental conditions prevailing in such periods (Rasheed \& Mustaquim 2010).

The size of the $C$. sapidus at first maturity obtained in this study was smaller than those cited in the literature for species in Brazil by Pereira et al. (2009) in the Baia de Babitonga $\left(\mathrm{L}_{50}=12.0 \mathrm{~cm}\right)$. Also bigger sizes were found in the United States by Van-Engel (1958) in Chesapeake Bay $\left(\mathrm{L}_{50}=11.2 \mathrm{~cm}\right)$; Fisher (1999) in Texas $\left(\mathrm{L}_{50}=12.0 \mathrm{~cm}\right)$, Guillory \& Hein (1997) in Louisiana $\left(\mathrm{L}_{50}=12.5 \mathrm{~cm}\right)$.

Factors that influence variation in size of maturity in C. sapidus can be: environmental (temperature and salinity), geographic and over-fishing, with morphological changes associated with the maturation of males and females. Lipcius \& Stockhausen (2002) found that in Chesapeake Bay (USA) the average size at maturity decreased by approximately 9\% annually between 1994 and 2000, due to environmental factors or over-fishing, which may reflect pressure on the hereditary characteristics of the population.

Individual fecundity obtained in this study was performed without the distinction of 
spawning related to the multiple clutches. Even so, the results showed higher spawning than observed by Van-Engel (1958) (from 1750000 to 2000000 ), by Hsueh et al. (1993) (from 2100000 to 3200000 ) and Pereira et al. (2009) (from 651241 to 170430). Lower results were also obtained by Hines (1982) (with 2750000 eggs) and Prager et al. (1990) (with 320000 eggs). Such oscillations may be caused by several factors such as: technique used for eggs counting, time and stage of embryonic development of eggs at the time of the count, genetic characteristics of populations, or the fact that the observation may have been made within a single spawning season (Dickinson et al. 2006).

Selectivity and exploitation may influence the hereditary characteristics of the population. Some possible scenarios should be evaluated whenever possible. They include: the average size of individuals, morphological maturity and fecundity. In the study area, the capture of C. sapidus is intense and selectively is targeted to adult males. Mendonça et al. (2010) noted that the captures have shown periods of significant fluctuations in the index of abundance in recent years, requiring management measures to be developed aiming at the rational use of resources.

Management of commercial crab fishery in other maritime countries using the basic "3-S" restrictions (sex, size, and season) have kept crabs stocks sustainable over the past several years (Helliwel 2009). In sum, our study concludes that in order to ensure resource sustainability, it is necessary to prohibit $C$. sapidus captures in the exit of the estuary, especially during summer and to limit the minimum capture size at $11 \mathrm{~cm}$ of carapace width. We firmly believe that this $11 \mathrm{~cm}$ size, if respected by the fishermen, can contribute effectively to sustainable resource exploitation and stock maintenance.

\section{ACKNOWLEDGMENTS}

The authors would like to thank Jocemar T. Mendonça for support logistic, Felipe Duarte for the suggestions for data processing,
Matheus Marcos Rotundo assistance in the preparation of the map, two anonymous reviewers provided comments on this manuscript and CAPES (Coordenação de Aperfeiçoamento de Pessoal de Nível Superior) for the Masters grants awarded to Joelson Musiello Fernandes.

\section{RESUMEN}

Hay pocos estudios sobre la ecología de $C$. sapidus en el Atlántico Sur, a pesar de su importancia económica en la región. El presente estudio tiene como objetivo conocer la fecundidad, periodo reproductivo y talla de primera madurez morfológica de las hembras de C. sapidus, con el fin de contribuir a una mejor comprensión de la especie en el Atlántico occidental, así como ayudar en la toma de medidas de gestión en la región. Las muestras fueron recolectadas mensualmente de enero a diciembre 2002 en sudeste del Brazil. Se recogieron 307 hembras: 78 jóvenes, 130 adultos y 99 ovígeras. Las hembras ovígeras mostró su intervalo de talla de $7.49-15.89 \mathrm{~cm}$ ancho del carapazón (AC) y se distribuyeron en todo el período de la muestra, con mayor incidencia entre diciembre y marzo. El inicio de la madurez morfológica $\left(\mathrm{L}_{50}\right)$ fue con la $\mathrm{AC}=10.33 \mathrm{~cm}$ y el tamaño que tenían todos los maduros $\left(\mathrm{L}_{100}\right)$ con $\mathrm{AC}$ de $11.20 \mathrm{~cm}$. Fecundidad individual osciló entre 689356 a 3438 122, con una media 2006 974. El AC mostró una tendencia positiva en el crecimiento con número de huevos y el peso del huevos. El conocimiento de los aspectos reproductivos de la población es importante en la definición de medidas de gestión para el uso sostenible con el fin de renovar y continuar con la misma.

Palabras clave: jaiba azul, biología reproductiva, recurso pesquero, estuario.

\section{REFERENCES}

Aguilar, R.T., H.A. Hines, T.G. Wolcott, D.L. Wolcott, M.A. Kramer \& R.N. Lipcius. 2005. The timing and route of movement and migration of post-copulatory female blue crabs, Callinectes sapidus Rathbun, from the upper Chesapeake Bay. J. Exp. Mar. Biol. Ecol. 319: 117-128.

Archambault, J.A., E.L. Wenner \& J.D. Whitaker. 1990. Life history and abundance of blue crab, Callinectes sapidus Rathbun, in Charleston Harbor, South Carolina. J. Bull. Mar. Sci. 46: 145-158.

Bernardes, M.E.C. \& L.B. Miranda. 2001. Circulação estacionária e estratificação de sal em canais estuarinos: simulação com modelos analíticos. Rev. Bras. Oceanogr. 49: 115-132. 
Buchanan, B.A. \& A.W. Stoner. 1988. Distribution patterns of blue crabs (Callinectes sp.) in a tropical estuarine lagoon. Estuaries 11: 231-239.

Carr, S.D., R.A. Tankersley, J.L. Hench, R.B. Forward \& R.A. Luettich. 2004. Movement patterns and trajectories of ovigerous blue crabs Callinectes sapidus during the spawning migration. Estuar. Coast. Shelf Sci. 60: 567-579.

Cargo, D.G. 1958. The migration of adult female blue crabs, Callinectes sapidus Rathbun, in Chincoteague Bay and adjacent water. J. Mar. Res. 16: 180-191.

Costa, T.M. \& M.L. Negreiros-Fransozo. 1996. Fecundidade de Callinectes danae Smith, 1869 (Crustacea, Decapoda, Portunidae) na região de Ubatuba (SP), Brasil. Braz. Arch. Biol.Techn. 39: 393-400.

Dickinson, G.H., D. Rittschof \& C. Latanich. 2006. Spawning biology of the blue crab, Callinectes sapidus, in North Carolina. Bull. Mar. Sci. 79: 273-285.

Knuckey, I.A. 1996. Maturity in male mud crabs, Scylla serrata, and the use of mating scars as a functional indicator. J. Crust. Biol. 46: 487-495.

Ferreira, L.S. \& F.D'Incao. 2008. Crescimento de Callinectes sapidus (Crustacea, Decapoda, Portunidae) no estuário da laguna dos Patos, RS, Brasil. Iheringia Ser. Zool. 98: 70-77.

Fisher, M.R. 1999. Effect of temperature and salinity on size at maturity of female blue crabs. Trans. Amer. Fish. Soc. 128: 499-506.

Guillory, V. \& S. Hein. 1997. Sexual maturity in Louisiana blue crabs. Proc. Louis. Acad. Sci. 59: 5-7.

Helliwel, V. 2009. Fisheries management for California Dungeness crab-adapting to change. Coast. Manage. 37: 491-500.

Hines, A.H. 1982. Allometric constraints and variables of reproductive effort in brachyuran crabs. Mar. Biol. 69: 309-320.

Hsueh, P.W., J.B. Mac Clintock \& T.S. Hopkins. 1993. Population dynamics and life history characteristics of the blue crabs Callinectes similes and $C$. sapidus in bay environments of the northern Gulf of Mexico. Mar. Ecol. 14: 239-257.

Ihaka, R. \& R. Gentleman. 1996. R: A language for data analysis and graphics. J. Comput. Graph. Stat. 5: 299-314.

Lipcius, R.N. \& A.H. Hines. 1986. Variable functional responses of a marine predator in dissimilar homogeneous microhabitats. Ecology 67: 1361-1371.

Lipcius, R.N. \& W.T. Stockhausen. 2002. Concurrent decline of the spawning stock, recruitment, larval abundance, and size of the blue crab Callinectes sapidus in Chesapeake Bay. Mar. Ecol. Prog. Ser. 226: 45-61.

Mantelatto, F.L.M. \& A. Fransozo. 1999. Reproductive biology and moulting cycle of the crab Callinectes ornatus (Decapoda, Portunidae) from the Ubatuba region, São Paulo, Brazil. Crustaceana 72: 63-73.

McClintock, J.B., K.R. Marion, J. Dindo, P.W. Hsueh \& R.A. Angus. 1993. Population studies of the Blue Crab in soft bottom, unvegetated habitats of a subestuary in the Northern Gulf of Mexico. J. Crust. Biol. 13: $551-563$.

Mendonça, J.T., J.R. Verani \& N. Nordi. 2010. Evaluation and management of blue crab Callinectes sapidus (Rathbun, 1896) (Decapoda - Portunidae) fishery in the Estuary of Cananéia, Iguape and Ilha Comprida, São Paulo, Brazil. Braz. J. Biol. 70: 37-45.

Motoda, S. 1959. Devices of simple plankton apparatus. Mem. Fac. Fish. 7: 73-94.

Millikin, M.R. \& A.B. Williams. 1984. Synopsis of biological data on the blue crab Callinectes sapidus Rathbun. FAO Fisheries Technical Paper 138: 43.

Oliveira, A., T.K. Pinto, D.P.D. Santos \& F.D’Incao. 2006. Dieta natural do siri-azul Callinectes sapidus na região estuarina da Lagoa dos Patos, Rio Grande, Rio Grande do Sul, Brasil. Iheringia Ser. Zool. 96: 305-313.

Ortiz-Leon, H.J., A. Jesus-Navarrete \& E.S. Cordero. 2007. Distribución espacial y temporal del cangrejo Callinectes sapidus (Decapoda: Portunidae) en la Bahía de Chetumal, Quintana Roo, México. Rev. Biol. Trop. 55: 235-245.

Pereira, M.J., J.O. Branco, M.L. Christoffersen, F. FreitasJunior, H.A.A. Fracasso \& T.C. Pinheiro. 2009. Population biology of Callinectes danae and Callinectes sapidus (Crustacea: Brachyura: Portunidae) in the south-western Atlantic. J. Mar. Biol. Ass. Unit. Kingdom 89: 1341-1351.

Pinheiro, M.A.A. \& A. Fransozo. 2002. Reproduction of the speckled swimming crab Arenaeus cribrarius (Brachyura: Portunidae) on the Brazilian coast, near 2330'. J. Crust. Biol. 22: 416-428.

Powers, L.W. 1977. A catalogue and bibliography to the crabs (Brachyura) of the Gulf of México. Contrib. Mar. Sci. 20: 1-190.

Prager, M.H., J.R. McConaugha, C.M. Jones \& P.J. Geer. 1990. Fecundity of blue crab, Callinectes sapidus, in Chesapeake Bay: biological, statistical and management considerations. Bull. Mar. Sci. 46: 170-179.

Rasheed, S. \& J. Mustaquim. 2010. Size at sexual maturity, breeding season and fecundity of three-spot swimming crab Portunus sanguinolentus (Herbst, 1783) (Decapoda, Brachyura, Portunidae) occurring in the coastal waters of Karachi, Pakistan. Fish. Res. 103: 56-62.

Ramach, S., M.Z. Darnell, N. Avissar \& D. Rittschof. 2009. Habitat use and population dynamics of blue crabs, Callinectes sapidus, in a high-salinity embayment. J Shellfish Res. 28: 635-640.

Severino-Rodrigues, E., F.C. Soares, R. Graça-Lopes, K.H. Souza \& V.O.C. Canéo. 2009. Diversidade e biologia 
de espécies de Portunidae (Decapoda: Brachyura) no estuário de Iguape, Ilha Comprida e Cananéia, São Paulo, Brasil. Bol. Inst. Pesca 35: 47-60.

Severino-Rodrigues, E., J. Musiello-Fernandes, A.A.S. Moura, G.M.P. Branco \& V.O.C. Canéo. 2012. Biologia reprodutiva de fêmeas de Callinectes danae (Decapoda, Portunidae) no Complexo EstuarinoLagunar de Iguape e Cananeia (SP). Bol. Inst. Pesca 38: 31-41.

Tankersley, R.A., M.G. Weiber, M.A. Sigala \& K.A. Kachurak. 1998. Migratory behavior of ovigerous blue crabs Callinectes sapidus: evidence for selective tidal-stream transport. Biol. Bull. 195: 168-173.

Taissoun, E.N. 1973. Biogeografia y ecologia de los cancrejos de la família "Portunidae" (Crustacea, Decapoda, Brachyura) em la costa Atlântica de América. Bol. Cent. Invest. Biol. 7: 7-23.
UNESCO. 2005. World Network of Biosphere ReservesSC/EES. The MAB Program. Marrakesh, Morocco.

Van-Engel, W.A. 1958. The blue crab and its fishery in Chesapeake bay. Part 1. Reproduction, early development, growth and migration. Com. Fish Rev. 20: 6-1.

Villasmil, L. \& J. Mendonza. 2001. La pesquería del cangrejo callinectes sapidus (decapoda: brachyura) en el lago de maracaibo, venezuela. Interciencia 26: 301-306.

Williams, A.B. 1974. The swimming crabs of the genus Callinectes (Decapoda: Portunidae). Fish. Bull. 72: 685-798.

Wolcott, T.G. \& A.H. Hines. 1990. Ultrasonic telemetry of small-scale movements and microhabitat selection by molting blue crab (Callinectes sapidus). Bull. Mar. Sci. 46: 83-94. 